\title{
INNOVATION LEVEL ON GLOBAL AND NATIONAL SCALE IN CONTEXT OF RENEWABLE ENERGY PRODUCTION IN LATVIA
}

\author{
Modrite Pelse, Lasma Aleksejeva, Dace Ziedina \\ Latvia University of Life Sciences and Technologies, Latvia \\ modrite.pelse@1lu.lv, lasma.aleksejeva@inbox.lv, dace.ziedina@varam.lv
}

\begin{abstract}
The EU energy policy focuses on broader use of renewable energy. Accordingly, it is currently important to invest in innovations in renewable energy production in order to meet the commitment in the future. In Latvia, according to some experts, innovation performance in renewable energy production is low compared with that in other bioeconomy industries in particular. The research aims to assess innovation performance in renewable energy production on a global and local scale, employing the Global Innovation Index indicators and expert opinions. The Global Innovation Index shows overall innovation performance in a country as a whole, while GDP per capita measures the economic potential of the country, including the capability to allocate resources to innovation. In terms of innovation in electrical energy production, Sweden and Finland were ranked high, while Luxembourg and Lithuania were ranked low. An analysis of the opportunities provided by a high development level of a country in terms of GDP per capita revealed that the potential for innovation in the EU was used the most successfully by Finland, the United Kingdom, Estonia and Bulgaria. Investment in knowledge and technology is a very important component for assessing the global innovation level; in the Baltic States Latvia and Lithuania - the investment could be rated as very low, while in Estonia - as low. This points to a threat to renewable energy production in the future. In Latvia, as pointed out by the experts, the government policy uncertainty affected innovation in the field of renewable energy the most. The fact that scientists and researchers rated innovation in the field of renewable energy in Latvia higher than the industry experts did could be viewed both positively and negatively, as this indicated that innovations were introduced in the energy industry, yet knowledge transfer to the energy industry lagged behind and was insufficient.
\end{abstract}

Keywords: global Innovation Index, renewable energy, innovation, growth.

\section{Introduction}

Technological progress has always played an important role in the development of countries, with a special focus being placed on innovation. To understand innovation and its role in development and resource use, it is important to comprehend the process of innovation. The Innovation Union assumes innovation as an ability of individuals, enterprises and nations to continuously create a future [1]. The trend is as follows: the more advanced a country applying support instruments aimed at fostering innovation and allocating a significant share of total investment to education, knowledge build-up and research is, the more successful in innovation the country is, which results in economic growth. The research aims to assess innovation performance in renewable energy production on a global and local scale, employing the Global Innovation Index indicators and expert opinions.

The European Union has made significant investments in renewable energy production, as the EU Member States in particular, compared with the other world regions or countries, are subject to various risks in international energy markets the most. A large gap between the production and consumption of oil and natural gas creates a situation where $54 \%$ of the energy consumed by the EU is imported [2]. This creates not only economic, but also political dependence of the EU. The EU energy policy focuses on renewable energy sources, as there are concerns about energy security, particularly during crises in energy markets. The public's requirements regarding the environment and fossil energy consumption increase [3]. It is believed that Latvia succeeds in energy production from renewable sources, electrical energy in particular, as its share of green energy varies in the range of 50-60\%. However, even though there is no reason to worry about renewable energy production in the future, today a lot of knowledge has to be built up and innovations have to be introduced in the energy sector. Innovations, including innovation development, in renewable energy production decrease the need to import energy and contribute to energy security. At the same time, Latvian scientists point to the instability of government policy decisions on support for renewable energy, which creates a negative attitude of the public to renewable energy [4]. Some EU Member States such as Sweden, Germany, Spain and Belgium can use their specific advantages, among them technological progress, to increase efficiency and transform their energy source structures in a way to be less dependent on energy imports. Nevertheless, the constraining factors of renewable energy technologies have to be noted, which particularly relates to the United Kingdom and France [5]. Research investigations have proved 
that technological solutions are the key factor contributing to higher efficiency in nuclear energy production in the countries generating this kind of energy. Consequently, innovations in the production and consumption of renewable energy become very urgent, which also require large investments in research and knowledge transfer [5].

Renewable energy production and sustainable resource use is one of the fields of bioeconomics that has been a special focus over the last decade due to environmental issues. An OECD report refers to bioeconomics as a science "transforming life science knowledge into new, sustainable, eco-efficient and competitive products" [6]. In bioeconomics, it is important to make investments in research and innovation development in biology-related fields in order to create economic benefits for the society [7]. Bioeconomy industries, among them renewable energy production in the Baltic Sea region, in Latvia too, have large potential, as, for example, the proportion of biomass sources in gross domestic energy consumption in Latvia is higher than the EU average. Biomass is relatively cheaper and less dependent on temporary changes in weather conditions [8]. There are many various research institutions in Latvia, yet innovation performance in this field is lowered by the dominance of low and medium low technologies; there is a weak link between researchers and entrepreneurs [9]. Latvian scientists refer to insufficient funding for science and research, pointing also to the low interest of entrepreneurs in funding innovation [10].

The strong link between innovation and financial resources is indicated by a number of definitions of innovation. Innovation encompasses all the activities to be done to create and sell in the market a new good or service. Innovation involves all the on-going processes in the society, beginning with education, scientific research, intellectual property protection, production management and market research through to sales. At the same time, the World Bank stresses that innovation and research are separate processes, and an innovation is not always created in the research process; it emerges in the entrepreneurship sector that brings it into the society, which depends on the responsiveness of the society [11]. One of the key drivers in the economy is the development of innovation processes and an effective innovation development system that ensures a fast and useful exchange of knowledge between the innovator and the relevant industry, which also avoids negative impacts on the environment [12]. Knowledge spillovers, as pointed out by J.Nig and V.Babich, give an opportunity to an enterprise to spread the new technologies and generate investment synergy; at the same time, enterprises insufficiently invest in research and development under equilibrium conditions, hoping to earn revenue from investments by others [13].

Innovation is an important indicator of development both on a national and on a global scale. An innovation is not always radically new - sometimes it is borrowed from another country and adapted to domestic conditions. However, it is undoubtedly the potential for development, which is based on knowledge. Technology transfer channels have to be sufficiently effective. The scientific literature discusses the issues in relation to clean energy.

\section{Materials and methods}

To achieve the research aim, the authors used research papers and summaries of national and foreign research investigations and employed the monographic method, analysis as well as induction and deduction.

To identify an innovation level, the present research employed indicators of the 2018 Global Innovation Index co-published by Cornell University, INSEAD, and the World Intellectual Property Organization (WIPO, an agency of the United Nations). An innovation level is measured on a 100point scale, determining a country's position among the other countries. The Global Innovation Index dataset has been publicly available since 2016, yet the authors decided to present the latest 2018 data after analysing the insignificant changes in index indicators over the last three years. The GII is calculated for seven input and output pillars: institutions; human capital and research; infrastructure; market sophistication; business sophistication; knowledge and technology outputs; creative outputs. The GII is determined for a total of 126 countries, yet the paper analyses in detail only the EU Member States. The research used Eurostat GDP per capita data and employed the grouping method for comparison of the data. 
The research did a survey of experts to compare innovation levels for bioeconomy industries. Scientists and researchers engaged in bioeconomics and specialists working in the bioeconomy sector and representing producer associations were surveyed in December 2017 and January-February 2018. The choice of the experts was based on the following decisive factor - activity in the bioeconomy sector for more than 15 years. Totally, 17 questionnaires filled in by bioeconomics scientists and researchers and 13 - by bioeconomy sector specialists - were received back. Three scientist and researcher questionnaires and one specialist questionnaire were excluded from data processing because the opinions expressed in the questionnaires could not be directly attributed to the selected bioeconomy industries. The industries represented by the experts were as follows: agriculture, livestock farming, fruit farming, renewable energy production and forestry (including woodprocessing). Totally, the experts were asked five open questions and one question requesting to rate innovation performance in the bioeconomy industry they represented on a scale from 1 to 10 with 1 being very poor and 10 being excellent.

\section{Results and discussion}

The 2018 Global Innovation Index analyses 126 countries [14] and assesses their performance in the field of energy; the countries represent $90 \%$ of the world's population and $96 \%$ of the world's GDP. Measuring innovation levels in the energy sector, the GII captures various facets, e.g., energy production, storage, distribution and consumption; it also takes into consideration fields such as education, infrastructure, the political environment and others. According to the GII, Switzerland with a score of 68 had the highest innovation level in the field of energy, while the Netherlands scored the highest among the EU Member States. Sweden scored slightly lower than the Netherlands, while Yemen with a score of 15 was ranked in the last, i.e. $126^{\text {th }}$ position. Romania was ranked the lowest among the EU Member States.

An essential role in innovation development is played by investment - how much a nation can afford to invest in it. One of the indicators that shows the investment capacity is GDP per capita. Figure 1 presents associations between the GII and GDP per capita as well as knowledge and technological levels for the EU Member States.

In Figure 1, arrows indicate the Member States whose rankings differed by five and more places. The authors categorised the Member States by knowledge and technology level into five groups. This indicator is a component of the overall GII that is subdivided into 14 sub-indicators such as patents, research papers, business start-ups, high technology application etc. The indicator particularly focuses on investment in innovation that later contributes to the other GII indicator groups. According to the overall GII, the Scandinavian countries - Sweden and Finland - had high rankings, yet Finland, which was ranked $4^{\text {th }}$, has to be particularly highlighted because it was ranked only $9^{\text {th }}$ in terms of GDP per capita. The United Kingdom was ranked $10^{\text {th }}$ in terms of GDP per capita, while the GII ranked it $3^{\text {rd}}$; however, the knowledge and technological level in the UK was ranked only average. This situation could lower the overall innovation level in the UK in the future and not let the country remain among the top countries such as the Netherlands and Sweden. Positive trends were demonstrated by the neighbouring country - Estonia - as well as Bulgaria, whose levels of investment in knowledge and technology among the EU Member States could be rated as low; the GII ranked Estonia nine places higher and Bulgaria five places higher than both countries could be ranked in terms of GDP per capita. In contrast, Luxembourg, Ireland and Lithuania, in terms of GDP per capita, could be ranked five or more places higher than the GII ranked them. For Luxembourg, this situation is less important, whereas for Lithuania and Ireland it indicates that an insufficient amount of funds was allocated to innovation, particularly in Lithuania, where the knowledge and technological level was also low. 


\begin{tabular}{|c|c|c|c|c|c|c|c|}
\hline \multirow{2}{*}{ 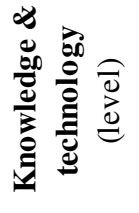 } & \multicolumn{3}{|c|}{ Global Innovation Index } & \multirow[b]{2}{*}{$\begin{array}{l}\text { Location } \\
\text { changes (more } \\
\text { than } 5 \text { places) }\end{array}$} & \multicolumn{3}{|c|}{ GDP per Capita } \\
\hline & $\begin{array}{l}\text { Rank } \\
\text { in EU }\end{array}$ & Country & $\begin{array}{c}\text { Global } \\
\text { Innovation } \\
\text { Index } \\
\text { score } 1-100\end{array}$ & & $\begin{array}{c}\text { GDP per } \\
\text { Capita } \\
\text { thousands }\end{array}$ & Country & $\begin{array}{l}\text { Rank } \\
\text { in EU }\end{array}$ \\
\hline VH & 1 & The Netherlands & 63.32 & & 106.37 & Luxembourg & 1 \\
\hline VH & 2 & Sweden & 63.08 & & 75.54 & Ireland & 2 \\
\hline M & 3 & United Kingdom & 60.13 & & 53.63 & The Netherlands & 3 \\
\hline $\mathrm{H}$ & 4 & Finland & 59.63 & & 51.47 & Sweden & 4 \\
\hline M & 5 & Denmark & 58.39 & & 50.43 & Germany & 5 \\
\hline $\mathrm{H}$ & 6 & Germany & 58.03 & & 49.88 & Denmark & 6 \\
\hline $\mathrm{H}$ & 7 & Ireland & 57.19 & & 49.87 & Austria & 7 \\
\hline M & 8 & Luxembourg & 54.53 & & 46.55 & Belgium & 8 \\
\hline M & 9 & France & 54.36 & & 44.33 & Finland & 9 \\
\hline L & 10 & Austria & 51.32 & & 44.12 & United Kingdom & 10 \\
\hline L & 11 & Estonia & 50.51 & & 43.76 & France & 11 \\
\hline M & 12 & Belgium & 50.50 & & 41.94 & Malta & 12 \\
\hline$L$ & 13 & Malta & 50.29 & & 38.29 & Spain & 13 \\
\hline M & 14 & Czech Republic & 48.75 & & 38.14 & Italy & 14 \\
\hline L & 15 & Spain & 48.68 & & 37.02 & Cyprus & 15 \\
\hline M & 16 & Cyprus & 47.83 & & 35.51 & Czech Republic & 16 \\
\hline L & 17 & Slovenia & 46.87 & & 34.41 & Slovenia & 17 \\
\hline L & 18 & Italy & 46.32 & & 33.03 & Slovakia & 18 \\
\hline L & 19 & Portugal & 45.71 & & 32.30 & Lithuania & 19 \\
\hline M & 20 & Hungary & 44.94 & & 31.75 & Estonia & 20 \\
\hline VL & 21 & Latvia & 43.18 & & 30.42 & Portugal & 21 \\
\hline L & 22 & Slovakia & 42.88 & & 29.52 & Poland & 22 \\
\hline L & 23 & Bulgaria & 42.65 & & 29.47 & Hungary & 23 \\
\hline L & 24 & Poland & 41.67 & & 27.74 & Greece & 24 \\
\hline VL & 25 & Lithuania & 41.19 & & 27.64 & Latvia & 25 \\
\hline VL & 26 & Croatia & 40.73 & & 24.51 & Romania & 26 \\
\hline VL & 27 & Greece & 38.93 & & 24.42 & Croatia & 27 \\
\hline L & 28 & Romania & 37.59 & & 21.69 & Bulgaria & 28 \\
\hline
\end{tabular}

Symbol:

\begin{tabular}{c|c} 
VH very hight level & low level
\end{tabular}

$\mathrm{H}$

hight level

VL very low level

Fig. 1. Associations between 2018 Global Innovation Index (GII) and gross domestic product (GDP) per capita for the EU Member States

The overall GII is comprised of seven pillars, and one of them pertains to knowledge and technology outputs (Figure 1). The ratings of all the seven pillars arranged hierarchically for the Baltic States are presented in Figure 2. For comparison, Ireland was included in the analysis as well. Energy and environmental issues were grouped under the pillar for infrastructure. A high innovation level in the field of energy production, particularly environment-friendly renewable energy production, was in Sweden and Finland that were ranked $7^{\text {th }}$ and $10^{\text {th }}$, respectively, out of 126 countries, whereas Lithuania and Luxembourg had the lowest ratings among the EU Member States, being ranked $88^{\text {th }}$ and $90^{\text {th }}$.

Ireland, which is similar to the Baltic States in terms of area and demonstrated positive trends regarding associations between GDP and the GII just as Estonia did, was included in the comparison of innovations levels across the Baltic States. An analysis of the significance of factors revealed that Latvia and Estonia had similar distributions of factor weights, while the distribution for Lithuania was different, with infrastructure being the key factor for the innovation level; this factor was a significant one for Estonia and Ireland, as it was ranked in the second place. However, large differences were observed, if comparing the weight of knowledge and technology outputs across the selected Member States. The Member States investing more in knowledge and technology (Figure 2) had higher rankings for overall innovation performance (Figure 1). For example, out of all the GII indicators, Ireland had the highest ranking for investment in knowledge and technology in particular, and among the EU Member States the GII ranked Ireland $7^{\text {th }}$, i.e. higher than the Baltic States: Estonia was $11^{\text {th }}$, Latvia $21^{\text {st }}$ and Lithuania $25^{\text {th }}$. This is also supported by the data presented in Figure 1 - investment in knowledge and technology was high in Ireland, low in Estonia and very low in Latvia and Lithuania. 

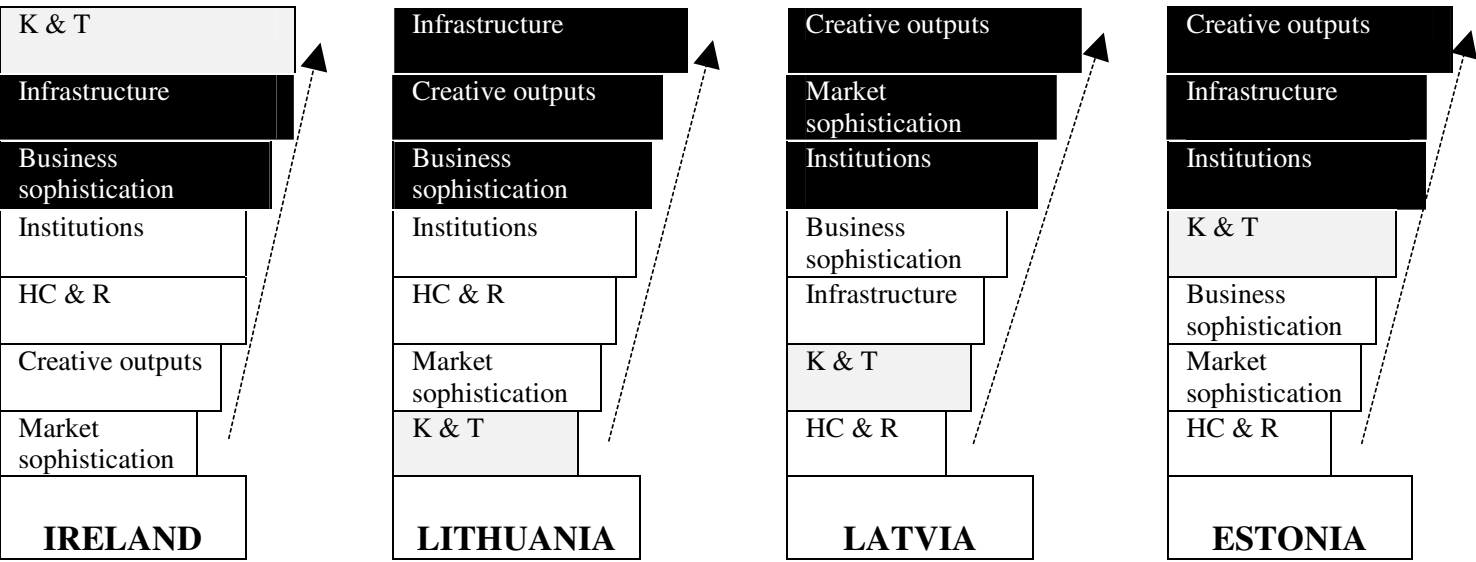

Notes: $\quad$ K\&T - Knowledge \& technology outputs; HC\&R - Human capital \& research Broader cells indicate a factor having a higher weight in the GII

Fig. 2. Comparison of factors affecting innovation in Ireland and the Baltic States in 2018 by group of Global Innovation Index (GII) indicators

In 2018, Estonia with an electricity output of $9128.8 \mathrm{kwh} / \mathrm{cap}$ had the highest rating of energy production, which belonged to the infrastructure category, among the Baltic States; the output in Latvia was 3-fold lower, while the output in Lithuania was $1463.2 \mathrm{kwh} / \mathrm{cap}$. An analysis of environmental performance (on a 100-point scale) revealed that among the Baltic States, the highest performance was found for Lithuania with 69.3 points, and Latvia, 66.1 points, while Estonia had a lower score of 64.3 points, which indicated that, if taking into account both the output of electricity and the environmental aspect, Latvia was the best performer. Besides, a comparison with the 2016 GII indicators revealed that the output of electricity in all Baltic States was approximately the same, while environmental performance in Estonia was rated the highest among the Baltic States at a score of 88.6. In the 3-year period, Estonia has lost this position, which is indicated by a larger amount of investment by Latvia in environmental-friendly energy production, i.e. renewable energy.

To assess the innovation level in the bioeconomy industries, including in renewable energy production, in Latvia the authors identified the opinions of Latvian scientists and researchers as well specialists working in the bioeconomy sector. The results are summarised in Figure 3. The Latvian scientists and researchers gave the highest ratings to innovation in fruit production, while the specialists rated innovation in forestry the highest - the ratings were above the average for the other bioeconomy industries. The rating of innovation in renewable energy production was below the average.
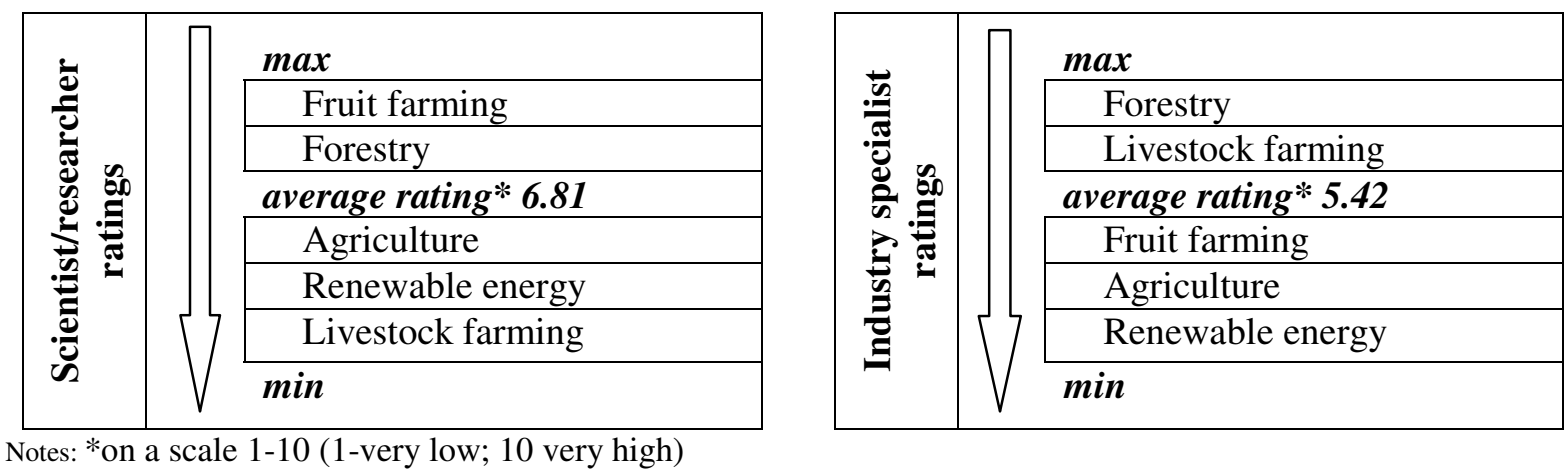

Fig.3. Ratings of innovation in bioeconomy industries in Latvia by scientists, researchers and specialists

The average rating of innovation in the bioeconomy industries by the scientists and researchers was 6.81 , while the rating for renewable energy production was 6.75 , which was higher than that for livestock farming. In contrast, the specialists working in the bioeconomy sector rated innovation in renewable energy production lower, at 4.0 , which was a very critical rating. Overall, one can conclude that compared with the specialists, the scientists and researchers were more optimistic and their ratings of innovation were higher, which indicated a lack of knowledge transfer, insufficient information 
exchange and a lack of cooperation. The Latvian scientists rated innovation performance as average or almost good, because the innovations were not known or not introduced in production and real practices. In addition, it was negatively affected by government policy decisions on renewable energy at the national level. As pointed out by the experts, a particularly hindering factor for renewable energy production in Latvia was the relevant legal framework and uncertainty over the government policy priorities as a whole, which had lasted not for a few years but for more than a decade.

\section{Conclusions}

1. Out of 126 countries, the 2018 GII ranked all the EU Member States among the top 50 nations, with the Netherlands being at the top of the EU and Romania being ranked the lowest. The rankings of innovation in electrical energy production for Sweden and Finland were high, whereas the rankings for Luxembourg and Lithuania were the lowest. This indicates insufficient financial resources and investment in energy production, particularly in Lithuania with its conventional economic pattern. In recent years, the opportunities provided by higher productivity were successfully used by Finland, the United Kingdom, Estonia and Bulgaria - among the EU Member States, the GII rated them higher than they could be rated in terms of GDP per capita. The present research has to be continued and complimented by data comparison and a correlation analysis in order to identify potential correlations between the GII and GDP not only within a particular year but also for other periods of time.

2. A trend is observed - the GII for the countries investing more in knowledge and technology is higher and the overall innovation performance is also higher. Investment in knowledge and technology in the Netherlands, Sweden, Finland, Germany and Ireland was rated as high or very high, and all the countries had high positions in the GII. This is confirmed by the comparison of the Baltic States and Ireland - the GII ranked Ireland the highest, Estonia with lower investment in knowledge and technology was ranked lower than Ireland, while Lithuania had the lowest ranking.

3. In Latvia, according to the experts, innovation performance in renewable energy production, which is one of the bioeconomy industries and which is important in the political agenda in the EU from both the energy security perspective and the environmental perspective, is overall lower than that in the other bioeconomy industries. The scientists, researchers and experts engaged in renewable energy production rated innovation performance in this industry on average at 6.75 , while the specialists working in this industry rated it the lowest among all the bioeconomy industries. The ratings by the scientists and researchers and by the specialists differed by more than two points. This indicates a lack of knowledge transfer in the industry or the perspective of the scientists and researchers pertained to some specific field and not to the entire renewable energy production industry. Despite the government policy uncertainty over renewable energy production in Latvia, scientists have to continue researching in this field, developing new technologies for renewable energy production and enhancing the existing ones, as it is expected that the current policy priorities in the EU and the world might not change in the future; on the contrary, the priorities might become more urgent.

\section{Acknowledgements}

The paper was supported by the national research programme "Latvian Heritage and Future Challenges for the Sustainability of the State" project "Challenges for the Latvian State and Society and the Solutions in International Context (INTERFRAME-LV)".

\section{References}

[1] Kao J. Innovation nation: how America is losing its innovation edge, why it matters, and what we can do to get it back. Free Press, 2007. 320 p.

[2] European Commission. Imports and secure supplies. [online] [09.01.2019]. Available at: https://ec.europa.eu/energy/en/topics/imports-and-secure-supplies

[3] Scholten D., Bosman R. The geopolitics of renewables; exploring the political implications of renewable energy systems. Journal of Technological Forecasting and Social Change, vol.103, 2016, pp. 273-283. 
[4] Rubins M., Pilvere I. Development of renewable energy policy in Latvia. Proceeding of the International conference "Economic Science for Rural Development", April 27-28, 2017, Jelgava, Latvia, No 44, pp.281-291.

[5] Gökgöz F., Güvercin M.T. Energy security and renewable energy efficiency in EU. Renewable and Sustainable Energy Reviews, vol. 96, 2018, pp. 226-239.

[6] OECD. The Bioeconomy to 2030: Designing a policy agenda, main findings, Organisation for Economic Cooperation and Development: Paris, France, 2009, 18 p.

[7] The white house. National bioeconomy blueprint. Washington: United States, 2012. 48 p.

[8] Kakitis A., Nulle I., Ozollapins M. etc. Assessment of combustion parameters of biomass mixtures. Proceedings of International conference "Engineering for rural development", May 2022, 2015, Jelgava, Latvia, vol.14, pp. 133-139.

[9] Zeverte-Rivza S., Popluga D., Pelse M. Innovations in Bioeconomy for Development of Sustainable Use of Natural Resources in Latvia. Proceedings of International conference SGEM "Energy and Clean Technologies Conference", vol.1, 2016, pp. 435-442.

[10]Pelse M., Ziedina D., Aleksejeva L. etc. Cooperation as a sustainable factor influencing innovation in regional development: the case of the bioeconomy in Latvia. Journal of Security and Sustainability Issues, vol. 7(3), 2018, pp. 581-590.

[11] Innovation policies for inclusive development. Scaling up inclusive innovations. [online] [22.01.2019]. Available at: https://www.oecd.org/innovation/inno/scaling-up-inclusiveinnovations.pdf.

[12]Libkovska U., Vasilevska D., Rivza B. etc. Increase of environmental technology competitiveness: Analysis of innovation potential in the Baltic States. Proceedings of International conference SGEM "Ecology, Economics, Education and Legislation", 2016, vol.3, pp. 273-280.

[13] Nig J., Babich V. R\&D investments in the presence of knowledge spillover and debt financing: Can risk shifting cure free riding? Journal of Manufacturing and Service Operations Management, vol.20, 2018, pp.97-112.

[14] Global Innovation Index 2018. Energizing the world with innovation. [online] [12.12.2018]. Available at: https://www.wipo.int/edocs/pubdocs/en/wipo_pub_gii_2018.pdf. 